\title{
Environmental assessment for results of the local territories positioning
}

\author{
Volodymyr Ustymenko ${ }^{1}$, Inna Zablodska ${ }^{2}$, Yuliia Rohozian ${ }^{1,{ }^{*}}$, Natalia Eremeeva ${ }^{1}$, and \\ Svitlana Hrechana ${ }^{2}$ \\ ${ }^{1}$ State institution "V.K. Mamutov Institute of Economic and Legal Research of the National Academy \\ of Sciences of Ukraine", 60 Taras Shevchenko Blv., 03057 Kyiv, Ukraine \\ ${ }^{2}$ Luhansk branch of the State institution "V.K. Mamutov Institute of Economic and Legal Research of \\ the National Academy of Sciences of Ukraine", 59-a Central Ave., 93400 Sievierodonetsk, Ukraine
}

\begin{abstract}
The purpose of the research is to construct positioning maps of local areas to assess the results of their positioning in terms of the environmental component of sustainable development. The article uses methods of analysis and synthesis, statistical and graphic, mapping method, comparative analysis and modelling, which made it possible to research the parameters and components of the local territories' (regions, cities and districts) positioning and to determine indicators for assessing their positions regarding economic, social and environmental components. Based on the rating estimates for the sustainable development of local areas, positioning maps have been constructed using the Ukrainian regions, districts and regional significance cities in the Luhansk region as the example. The article results proposed to expand the environmental indicators list for the positioning implementation based on the environmental assessment in the local level, which will allow the scientific and practical approach to assess the territorial units' positions from the sustainable development point of view.
\end{abstract}

\section{Introduction}

The dynamic and changing conditions of the world economy necessitate an attractiveness increase of each local area from an investment point of view. To achieve this goal, it is no longer enough to pay attention only to the growth of statistical economic indicators, it is important to strengthen and improve the existing economic, social and environmental positions of the territory (according to Ukraine's implementation of the sustainable development concept at all levels of power). In conditions when Ukrainian cities have already accumulated some experience in the marketing implementation in the main life spheres, territorial communities that have recently amalgamated are just beginning to think about the importance of forming their reputation characteristics. Such characteristics developed and tested in practice over the years, however, they based on specific parameters of the territory positioning, which personify the singular features and unique properties for the particular territory.

\footnotetext{
${ }^{*}$ Corresponding author: j.s.rohozian@gmail.com
} 


\section{Material and methods}

The districts and cities of the Luhansk region, which is located in the east of Ukraine and now has special political, environmental and other conditions for development, taking into account the conduct of active hostilities since 2014, represent the territory of the scientific research approbation.

The theoretical and methodical basis of the research presented by lays of the sustainable development concept, regional and local economy, works of the foreign and domestic scientists, in particular J. Milán-García, J. Uribe-Toril [1], I. Budnikevich [2], Z. Siryk [3], I. Mikhno, V. Koval [4], M. Munasinghe [5], J. Xiangfeng, U. Muhammad [6], O. Trokhymets [7], K. Kostetska, N. Khumarova [8].

The information base presented by the Resolution of the Cabinet of Ministers of Ukraine about the method for evaluating the regional effectiveness [9], the Order of the Ministry for Community and Territory Development of Ukraine about the regional ranking assessment for 2019 [10], analytical materials about environmental situation in the Donetsk and Luhansk regions by the Ministry of the Temporarily Occupied Territories and Internally Displaced Persons of Ukraine [11], as well as rating assessment of the regional significance cities and regional districts for 2019 [12].

The article purpose arises the construction of positioning maps using the example of the Ukrainian regions, districts and regional significance cities of the Luhansk region to assess the positioning results for local territories. This scientific research used the following methods: analysis and synthesis, statistical and graphic, method mapping, benchmarking, and modelling. The positioning maps construction have been carried out using the GeoGebra software for visualizing the studied objects as well as instrumental measurement of the positioning results in terms of the environmental component of sustainable development.

\section{Calculation}

In the constructing process of positioning maps for the local territories based on certain parameters, each of the studied administrative-territorial unit (region, district and city) is a set of ratings for a certain direction of sustainable development (economic, social and environmental).

The overall rating calculated according to the formula:

$$
O R_{\text {dir }}=\sum_{i=1}^{N_{\text {dir }}} R_{\text {dir }}^{i} / N_{\text {dir }}
$$

where $O R_{d i r}$ - overall rating in the direction $\left(O R_{\text {econ }}, O R_{s o c}, O R_{\text {env }}\right)$;

$R_{d i r}^{i}$ - rating scores for the corresponding indicators in the direction;

$N_{\text {dir }}$ - total number of indicators in the direction.

This traditional approach allows preserving the quantification of the received ratings and determining the overall rating in the sustainable development direction or component based on the grouping results of the local positioning parameters. Environmental assessment for the results of the local territories positioning in Ukraine also based on a spatial approach. 


\section{Results and discussion}

The most successful, in our opinion, tool for such a graphic image is the positioning map of local area - a graphic model [13], on the coordinate axes of which the most significant evaluation and selection criteria are indicated. If we take into account the amalgamated territorial communities, it is complicated by the fact that today there are no official statistics on the sustainable development directions. However, local areas should focus on comprehensive assessments, which formed and published by the Ministry for Community and Territory Development of Ukraine in accordance with the Resolution of the Cabinet of Ministers of Ukraine "On approval of the Procedure and Methodology for monitoring and evaluating the effectiveness of the implementation of state regional policy" [9].

The annual assessment of the regional socio-economic development carried out based on available official statistics and information from central and local executive authorities for 62 indicators. It characterizes the situation in 12 areas in different areas of their development, determines the place of each region in a separate area, summarizing the ranking in all areas of assessment. These rating structured in a certain way, we propose to use as the parameters necessary for building maps of positioning regions (Table 1).

Table 1. Determination for the positioning parameters in the regional level*.

\begin{tabular}{|c|c|}
\hline Parameters & Direction content \\
\hline \multicolumn{2}{|r|}{ Economic component } \\
\hline $\begin{array}{l}\text { Economic and social } \\
\text { cohesion }\end{array}$ & $\begin{array}{l}\text { Indicators (3) that comprehensively characterize the living standard of } \\
\text { the population and the state of the regional economy development. }\end{array}$ \\
\hline Economic efficiency & $\begin{array}{l}\text { Indicators (7) characterizing the state of the real economy sector } \\
\text { development and the prices level in the consumer market (price index). }\end{array}$ \\
\hline $\begin{array}{c}\text { Investment and innovative } \\
\text { development and foreign } \\
\text { economic cooperation }\end{array}$ & $\begin{array}{l}\text { Indicators (6), which characterize the situation with attracting } \\
\text { investment resources, the innovations development and the foreign } \\
\text { trade state in goods (export) }\end{array}$ \\
\hline \begin{tabular}{|l} 
Financial self-sufficiency \\
\end{tabular} & $\begin{array}{l}\text { Indicators (4), characterizing the growth dynamics of budget revenues, } \\
\text { the capital expenditures volume per capita and repayment of tax debt }\end{array}$ \\
\hline $\begin{array}{c}\text { Development of small and } \\
\text { medium-sized businesses }\end{array}$ & $\begin{array}{l}\text { Indicators (4), which determine the business entities number and the } \\
\text { share of the sales volume of their products }\end{array}$ \\
\hline \multicolumn{2}{|r|}{ Social component } \\
\hline Labor market efficiency & $\begin{array}{l}\text { Indicators (6), which comprehensively characterize the situation with } \\
\text { regard to unemployment and employment, the dynamics of real wages } \\
\text { growth and repayment of arrears on its payment, labor productivity }\end{array}$ \\
\hline Infrastructure development & $\begin{array}{l}\text { Indicators (6), characterizing the situation in the field of housing } \\
\text { construction, transport and road infrastructure development, the volume } \\
\text { of freight traffic by road and rail, the volume of housing commissioned }\end{array}$ \\
\hline $\begin{array}{l}\text { Availability and quality of } \\
\text { educational services }\end{array}$ & $\begin{array}{l}\text { Indicators (7), characterizing the connection level of rural educational } \\
\text { institutions to the Internet, the provision of children transportation to } \\
\text { places of study and the general level of education quality }\end{array}$ \\
\hline $\begin{array}{c}\text { Availability and quality of } \\
\text { healthcare services }\end{array}$ & $\begin{array}{l}\text { Indicators (5), characterizing the mortality and birth rate, the total } \\
\text { duration life, the availability of outpatient services and the state of } \\
\text { measures implementation to combat the incidence of active tuberculosis }\end{array}$ \\
\hline $\begin{array}{l}\text { Social protection and } \\
\text { safety }\end{array}$ & $\begin{array}{l}\text { Indicators (4), characterizing the level of provision of social services to } \\
\text { the most vulnerable segments of the population, the safety of life }\end{array}$ \\
\hline \multicolumn{2}{|r|}{ Environmental component } \\
\hline $\begin{array}{c}\text { Sustainable use of natural } \\
\text { resources and environment } \\
\text { quality }\end{array}$ & $\begin{array}{l}\text { Indicators (5), characterizing the situation in the field of environment } \\
\text { and the effectiveness of environmental protection measures }\end{array}$ \\
\hline $\begin{array}{l}\text { Renewable energy and } \\
\text { energy efficiency }\end{array}$ & $\begin{array}{l}\text { Indicators (7), which characterize the state of energy efficiency } \\
\text { measures, the use of renewable energy sources and alternative fuels }\end{array}$ \\
\hline
\end{tabular}

* Source: compiled by the authors based on [10] 
Local territories that are the first to face the problems of deteriorating the environmental state of their own territories, destruction threats of a comfortable environment for life in the regions, districts and cities associated with negative changes in ecosystems [11]. All these existing demands require the introduction of a prevailing environmental approach in the territories' positioning [14]. Nevertheless, in practice it faces with the complete opposite, since the official system of statistical observations demonstrates the information lack. We propose to achieve a certain levelling of the negative impact by constructing positioning maps, mainly according to the environmental assessment criterion.

So, using the rating regional assessment for 2019 [10] and the principle of plotting points in a Cartesian coordinate system $(\mathrm{X} ; \mathrm{Y})$, the calculating results for the positioning parameters' values according to the formula presented at the beginning of this article (Table 2), it needs to build two-dimensional positioning maps according to different combinations of environmental assessment (Fig. 1).

Positioning visualization carried out using GeoGebra software, which allows having accurate analytical studies and thoroughly investigating the results of positioning territorial units thanks to the visual programming of dynamic applets.

The graphic reflection of the relationship between the positions of the regions in Ukraine in terms of economic-environmental and socio-environmental components showed a wider distribution of regions on the economic measurement scale and a greater concentration when considering the social sphere.

Table 2. Calculating results of the regional coordinates for building positioning maps*.

\begin{tabular}{|c|c|c|c|c|c|c|}
\hline \multirow{2}{*}{$\begin{array}{l}\text { The regions } \\
\text { of Ukraine }\end{array}$} & \multicolumn{2}{|c|}{$\begin{array}{c}\text { Rating based on the } \\
\text { assessment } \\
\text { of the economic component }\end{array}$} & \multicolumn{2}{|c|}{$\begin{array}{l}\text { Rating based on the } \\
\text { assessment } \\
\text { of the social component }\end{array}$} & \multicolumn{2}{|c|}{$\begin{array}{l}\text { Rating based on the } \\
\text { assessment of the } \\
\text { environmental component }\end{array}$} \\
\hline & $\sum O R_{\text {econ }}$ & $\begin{array}{c}O R_{\text {econ }}=\sum O R_{\text {econ }} / \\
5(X)\end{array}$ & $\sum O R_{s o c}$ & $\begin{array}{c}O R_{s o c}=\sum_{5(X)} O R_{s o c} \\
\end{array}$ & $\sum O R_{e n v}$ & $\begin{array}{c}O R_{e n v}=\sum_{2(Y)} O R_{e n v} \\
2(Y)\end{array}$ \\
\hline Cherkasy & 79 & 16 & 57 & 11 & 26 & 13 \\
\hline Chernihiv & 73 & 15 & 83 & 17 & 22 & 4 \\
\hline Chernivtsi & 64 & 13 & 44 & 9 & 26 & 13 \\
\hline Dnipropetrovsk & 39 & 8 & 49 & 10 & 25 & 13 \\
\hline Donetsk & 85 & 17 & 72 & 18 & 50 & 25 \\
\hline $\begin{array}{l}\text { Ivano- } \\
\text { Frankivsk }\end{array}$ & 73 & 15 & 53 & 11 & 36 & 18 \\
\hline Kharkiv & 56 & 11 & 46 & 9 & 38 & 19 \\
\hline Kherson & 54 & 11 & 104 & 21 & 15 & 8 \\
\hline Khmelnytsky & 86 & 17 & 66 & 13 & 19 & 10 \\
\hline Kirovohrad & 55 & 11 & 58 & 12 & 26 & 13 \\
\hline Kyiv & 39 & 8 & 47 & 9 & 37 & 19 \\
\hline Luhansk & 102 & 20 & 66 & 17 & 47 & 24 \\
\hline Lviv & 49 & 10 & 56 & 11 & 18 & 9 \\
\hline Mykolaiv & 57 & 11 & 65 & 13 & 25 & 13 \\
\hline Odesa & 71 & 14 & 47 & 9 & 26 & 13 \\
\hline Poltava & 53 & 11 & 93 & 19 & 25 & 13 \\
\hline Rivne & 51 & 11 & 92 & 18 & 24 & 12 \\
\hline Sumy & 89 & 18 & 52 & 10 & 37 & 19 \\
\hline Ternopil & 71 & 14 & 54 & 11 & 23 & 12 \\
\hline Vinnytsia & 55 & 11 & 63 & 13 & 26 & 13 \\
\hline Volyn & 77 & 15 & 80 & 16 & 10 & 5 \\
\hline Zakarpattia & 67 & 13 & 67 & 13 & 18 & 9 \\
\hline Zaporizhzhia & 67 & 13 & 82 & 16 & 36 & 18 \\
\hline Zhytomyr & 82 & 16 & 87 & 17 & 17 & 9 \\
\hline
\end{tabular}

* Source: compiled by the authors based on [10] 

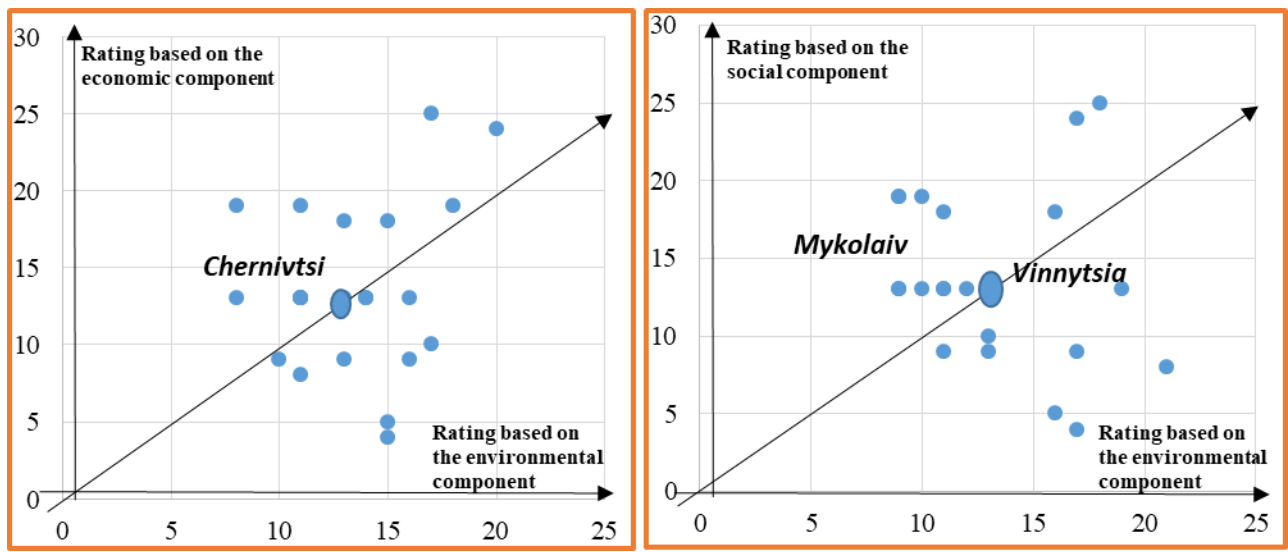

Fig. 1. Positioning maps based on environmental component of the regions in Ukraine.

The disagreements between the regions over positioning in the environmental sphere are quite significant on both maps. The constructed vector of balanced positioning made it possible to determine local territories (in this case, regions) that have the most balanced position in terms of the environmental component, such as Chernivtsi, Vinnytsia and Mykolaiv regions. The closest to this vector are the Odesa, Lviv, Zakarpattia and Khmelnitsky regions. Some of the worst positions are occupied by the post-conflict territories of Donetsk and Luhansk regions, which have an overall rating of 17 and 20 in terms of the economic component, respectively, in terms of social - 18 and 17, and in terms of environmental -25 and 24 [10].

According to experts, the Luhansk region has significant violations of ecosystems and natural areas, destruction of industrial and environmentally hazardous facilities, pollution of drinking water sources, land, atmospheric air, and disturbance of the geological environment [11]. On its example, it is necessary to demonstrate the application of the proposed approach to the construction of positioning regional maps, which at other levels of local unites, namely, districts and cities, requires minor adjustments in the content of the assessment parameters associated with the specifics of regulation.

Assessment results of the socio-economic development of districts and cities in the Luhansk region annually carried out by the regional state administration [12]. Unlike the rating assessments carried out at the regional level, this order provides for the use of 51 indicators for 10 areas.

Now the economic component includes four areas: "Economic efficiency" (9 indicators), "Investment development" (5), "Financial self-sufficiency" (4) and "Development of small and medium-sized businesses" (3). Social component - "Labor market efficiency, social protection and safety" (6), "Availability and quality of educational services" (5), "Availability and quality of healthcare services" (2), "Availability and quality of cultural and sportive services" (4). The environmental component is formed by 2 directions: "Infrastructure development and environmental quality" (8) and "Renewable energy and energy efficiency" (3).

Applying the proposed methodical approach at the regional level and relying on the data [12], it is important to construct the positioning maps of the Luhansk districts (Fig. 2) and regional significance cities (Fig. 3). It is necessary to do in the following combination: rating by the environmental and the economic component of the local territories' development; rating for the environmental and social component of the area's development. 

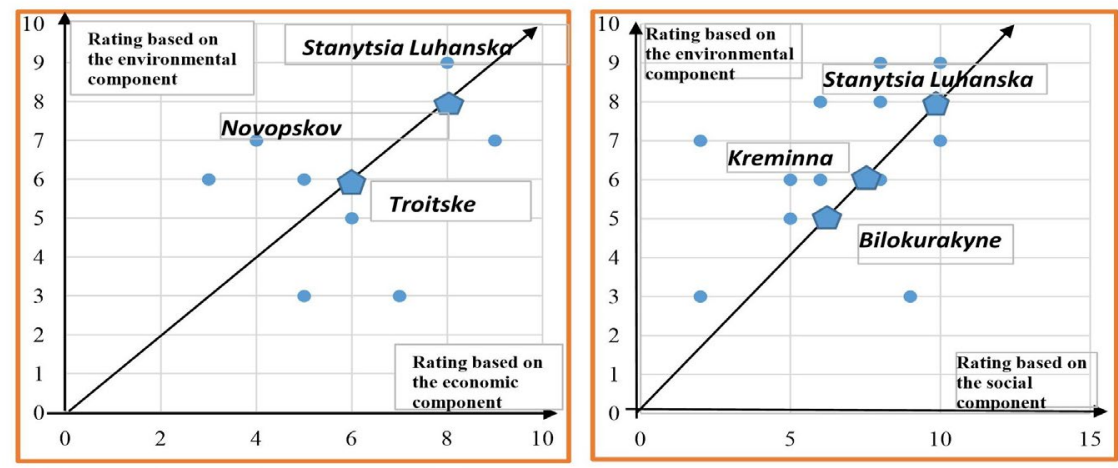

Fig. 2. Positioning maps based on environmental component of the districts in the Luhansk region.

The positioning maps of the districts in the Luhansk region are quite similar to the regional tendencies of the mutual disposition of local-level subjects, namely, significant dispersion in space with an economical-environmental assessment and a greater accuracy in terms of the socio-environmental component. This may indicate an increase in the attention of local self-government bodies to pursuing not so much a balanced policy of socioeconomic development as its orientation towards the primary satisfaction of social needs.
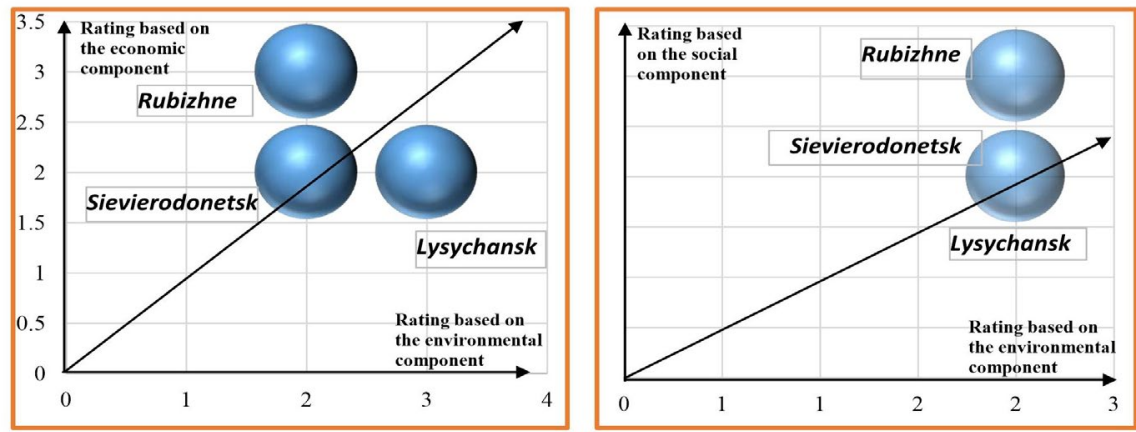

Fig. 3. Positioning maps based on environmental component of the Luhansk cities of regional significance.

The constructed vector of balanced local positioning made it possible to determine that the Stanytsia Luhanska district has the most balanced position, despite the fact that it belongs to the most affected post-conflict territories; it is the closest to the territories not controlled by the Ukrainian government. Novopskov, Troitske, Kreminna and Bilokurakyne districts are also pursuing a balanced policy of environmental development, allowing them to be in the most favorable economic or social perspective. Among the cities of regional significance of the Luhansk region, the best-balanced positions belong to the Sievierodonetsk and the Lysychansk cities.

The list of traditional measures should precede by the environmental assessment in the local level and include such indicators as: rational and economical use of natural resources based on the widespread use of the latest technologies; implementation of measures to prevent damage, pollution, depletion of natural resources, negative impact on the environment; implementation of measures for the reproduction of renewable natural resources; application of biological, chemical and other methods to improve the quality of natural resources, ensuring environmental protection and safety of public health; preservation of territories and objects of the natural reserve fund, as well as other territories subject to special protection, etc. [15]. 


\section{Conclusions}

Thus, the positioning map of local territories is a graphic model that allows visualizing the results of assessing the sustainable (economic, social and environmental) development in the local level (regions, districts and cities). To construct positioning maps of local territories official statistics and information from central and local executive authorities were used - 62 indicators, which are grouped in 12 areas in environmental, social and economic components with the subsequent determination of the overall rating. Positioning maps of the regions, districts and cities of regional significance built taking into account the prevailing environmental approach in the following combination: rating for the environmental and economic component of the local areas' development; rating for the environmental and social component for the development of local territories. The use of the vector of balanced positioning made it possible to determine the regions, districts and cities that have the most balanced positions, taking into account the triad of sustainable development directions. Based on the results of the local territories positioning, it was determined that the most balanced position in terms of the environmental component belongs to Chernivtsi, Vinnytsia and Mykolaiv regions, Stanytsia Luhanska, Novopskov, Troitske, Kreminna and Bilokurakyne districts of the Luhansk region, Sievierodonetsk and the Lysychansk cities of regional significance.

It proposed that following indicators should include to the environmental assessment: maximum permissible norms for discharges of harmful substances into water, maximum permissible norms for emissions of harmful substances in the air and maximum permissible norms for the concentration of naughty substances in the ground. However, for a more effective tool for assessing the local territories positions in the context of their sustainable development, in the future, it is proposed to use a Cartesian coordinate system in space, which will allow building cubes for positioning local territories (regions, districts and cities) using the GeoGebra software.

\section{References}

1. Milán-García, J., Uribe-Toril, J., Ruiz-Real, J.L., \& de Pablo Valenciano, J. (2019). Sustainable local development: an overview of the state of knowledge. Resources, 8 (1), 1-18. https://doi.org/10.3390/resources 8010031

2. Budnikevich, I., Kolomytseva, O., Krupenna, I., \& Zablodska, D. (2021). Positioning of the Amalgamated Territorial Communities of Ukraine through the Sustainable Development in the Conditions of Military Actions. Problemy Ekorozwoju, 16 (1), 103 112. https://doi.org/10.35784/pe.2021.1.11

3. Siryk, Z., Popadynets, N., Pityulych, M., Chakii, O., Irtyshcheva, I., Panukhnyk, O., \& Lysyak, N. (2021). Decentralization of local self-government under the conditions of administrative-territorial reform in Ukraine. Accounting, 7, 1-10.

4. Mikhno, I., Koval, V., Shvets, G., Garmatiuk, O., \& Tamošiūnienè, R. (2021). Discussion: Green Economy in Sustainable Development and Improvement of Resource Efficiency. Central European Business Review, 10, 1-15. https://doi.org/10.18267/j.cebr.252

5. Munasinghe, M. (2020). COVID-19 and sustainable development. International Journal of Sustainable Development, 23 (1/2), 1-24. https://doi.org/10.1504/IJSD.2020.112182

6. Xiangfeng, J., Muhammad, U., Shahid, A., Wajid, A., Kai, T., \& Zeeshan, K. (2020). Does fiscal decentralization and eco-innovation promote sustainable environment? A case study of selected fiscally decentralized countries. Sustainable Development, 29 (1), 79-88. https://doi.org/10.1002/sd.2132 
7. Koval, V., Mikhno, I., Trokhymets, O., Kustrich, L., \& Vdovenko, N. (2020). Modeling the interaction between environment and the economy considering the impact on ecosystem. E3S Web Conferences, 166, 13002. https://doi.org/10.1051/e3sconf/202016613002

8. Kostetska, K., Khumarova, N., Umanska, Y., Shmygol, N., \& Koval, V. (2020). Institutional qualities of inclusive environmental management in sustainable economic development. Management Systems in Production Engineering, 28 (2), 1522. https://doi.org/10.2478/mspe-2020-0003

9. Verkhovna Rada of Ukraine. (2015). On approval of the Procedure and Methodology for monitoring and evaluating the effectiveness of the implementation of state regional policy. № 856 Appendix 2.

10. Ministry for Community and Territory Development of Ukraine. (2020). Regional Ranking Assessment for 2019. https://www.minregion.gov.ua/napryamki-diyalnosti

11. Šipilova, V., Ostrovska, I., Jermolajeva, E., Aleksejeva, L., \& Oḷehnovičs, D. (2017). Evaluation of Sustainable Development in Rural Territories in Latgale Region (Latvia) by Using the Conception of Smart Specialization. Journal of Teacher Education for Sustainability, 19 (1), 82-105. https://doi.org/10.1515/jtes-2017-0006

12. Bondar, O., Ulitsky, O., \& Yermakov V. (2018). Report on the results of studying the environmental situation in the Donetsk and Luhansk regions. Ministry of the Temporarily Occupied Territories and Internally Displaced Persons of Ukraine. Kyiv: Planeta.

13. Luhansk Regional State Administration. (2020). Rating assessment of the regional significance cities and regional districts for 2019. http://loga.gov.ua/oda/about/depart/economy/reytingova_ocinka

14. Zablodska, I., Hrechana, S., \& Zablodska, D. (2020). The identification of the Luhansk region and the region act's according to the qualification of their sustainable development in the conditions of the joint forces. Problemy Ekorozwoju, 15 (1), 197210. https://doi.org/10.35784/pe.2020.1.21

15.Zos-Kior, M., Kuksa, I., Samoilyk, I., \& Storoška, M. (2017). Methodology for assessing the countries' globalization development. Economic Annals-XXI, 168 (1112), 4-8. https://doi.org/10.21003/ea.V168-01 